\title{
Increasing Character Education of Children with Learning Disabilities through Story Telling Method in Civic Education
}

\author{
Fatmawati \\ PLB \\ Universitas Negeri Padang \\ Padang, Indonesia \\ fatmawati@fip.unp.ac.id
}

\author{
Nurhastuti \\ PLB \\ Universitas Negeri Padang \\ Padang, Indonesia \\ nurhastuti@fip.unp.ac.id
}

\begin{abstract}
Children with learning disabilities have limitations in capturing and understanding the lessons provided by the teacher. Therefore we need a special approach in providing educational materials to children's learning disabilities. One way that felt most suitable in providing character education materials for children with learning disabilities is through storytelling. Therefore, the aimed of this research is to find the contribution of character education with storytelling in the field of study citizenship education in an effort to improve the soft skills of children's learning disabilities. The results of this study are the implementation of storytelling methods in improving the character education of children with learning disabilities in SDN 09 Kota Padang is done by using storytelling media because the story has an unquestionable educational value, its broad usage with colored illustrations, a concise storyline with realistic person's characteristic attract all children of different ages.
\end{abstract}

Keywords-character education; learning disabilities; civic education

\section{INTRODUCTION}

Teachers often face children who have learning disabilities. Learning disabilities are an umbrella term for a wide variety of learning problems. A learning disability is not a problem with intelligence or motivation. Children with learning disabilities aren't lazy or dumb [1]. In fact, most are just as smart as everyone else. Their brains are simply wired differently. This difference affects how they receive and process information [2].

Learning disabilities are conditions that affect how a person learns to read, write, speak, and calculate numbers. They are caused by differences in brain structure and affect the way a person's brain processes information [3]. One way to stimulate the spirit and confidence of children with learning disabilities is through character education. Character education is an educational movement that supports the social, emotional and ethical development of students. It is the proactive effort by schools, districts, and states to instill in students important core, ethical and performance values such as caring, honesty, diligence, fairness, fortitude, responsibility, and respect for self and others [4].
One of the most perceived ways in giving character education materials for children with learning disabilities is through the method of storytelling. The storytelling method is closely related to the cognitive and moral development of children. Children have a natural interest to listen, read and understand stories. Hence, this method can stimulate and motivate students in the learning process [5]. Teachers can help children learn moral values through stories and scenarios. After the teacher tells a story the pupils should be given the opportunity to create discussions and interactions between peers so that children can learn what is "wrong" or "right" through problem solving and conflict in the individual consciousness and make collective decisions [6].

In this research, efforts to improve character education through telling methods for students with learning disabilities will be applied to the subjects of citizenship education. The selection of this subject is based on the consideration that citizenship education is a learning material that is closely related to the values of a nation's character. Citizenship education is one of the concepts of education that serves to form students as citizens who have character. The relevance of citizenship education to the development of the character of students with learning disabilities is because citizenship education has dimensions that can not be separated from the aspect of character formation and public morality of citizens.

\section{METHODS}

Type of this research is a collaborative classroom action research conducted to improve and improve the quality of learning. Classroom Action Research is a method of finding out what works best in your own classroom so that you can improve student learning [7]. Classroom Action Research is more systematic than personal reflection but it is more informal and personal than formal educational research. The goal of Classroom Action Research is to improve your own teaching in your own classroom, department, or school. While there is no requirement that the findings be generalized to other 
situations the results can add to knowledge base [8].

\section{DISCUSSION}

In assessing the objective condition of children with learning disabilities in the implementation of character education in citizenship education through storytelling method the researchers looked from six aspects, namely: the willingness to learn students; ability to overcome learning problems; diligence on the task; learning independence; desire for achievement; and learning objectives.

1. Willingness to learn.

a. Motivation to learn

Based on the results of observations, after learning character education through the story figures or heroes show that 10 students from 13 students have a very strong learning motivation.

b. The Spirit of Following Lessons

After the method of learning character education through the story of a hero, if viewed from the aspect of the spirit of following the lesson, students experience improvement. This is based on the results of observation shows that 11 students from 13 students have the spirit to follow a very strong lesson.

2. Ability to overcome learning problems.

a. Patience in Following Lessons

After the method tells the story of character education of the hero or the hero there is an increasing number of students who pay attention to the same subject that is being faced.

b. Discipline in Use of Time

After the method tells the story of character education from the hero, there is a significant change.

3. Diligence on the task.

a. Level of Task Settlement

Based on the results of field observations, after the method tells the story of exemplary figures or heroes show that 11 students from 13 students have high motivation to do the task.

b. Always Doing Timely Duties

Based on observations in the classroom it can be seen that previously only 6 students who always do the task on time, while after the action to 12 . This shows that the exemplary character values of heroes and heroes are very influential on good student behavior in the classroom.

4. Learning independence.

a. Doing Tasks Without the Help of Others That many positive things affect the students who get from the values of exemplary characters of characters and heroes. Therefore, character education is important for students in changing their mindset and daily behavior.

b. Trying to Study Diligently

Students tend to be able to complete assigned tasks according to the target set by the teacher and have an improved repeat score. The importance of good exemplary figures or hero characters in order to provide changes for students to become more.

5. Desire for achievement.

a. Want to Become a Champion of Class

Character education through the storytelling method is able to change the mindset of the students that they can become champions of the class and they want to become a champion of the class, with embedded intentions and mindsets like this automatically what children do what the children do will be in accordance with what is thought and want it.

b. Motivation Gets Good Value

Motivation is like a child's early stepping to the next step. Students SDN 09 Kota Padang finally sure any motivation, would want the best for him. Motivation to get good grades is to learn hard and never give up. These values are then quite embedded in the students after the character education.

6. Learning objectives

a. Changes in Attitudes to Lessons

Generally students concentrate on subjects of mathematics, Indonesian language, science and social studies. Now students are aware that every subject is important to him. So the embedded pattern of piker that certain subjects will help in solving problems that exist in other subjects.

b. Change of Attitude to Learning Outcomes

After studying diligently and earnestly, the result is left to the Almighty. It is understood by the students that it is not the end result that must be achieved but the process to get results from learning that must be addressed with hard work and never give up.

\section{CONCLUSION}

Character education of children with learning disabilities in SDN 09 Kota Padang before applied the storytelling method is still less than optimal and still need to be improved. It is known from the number of children who have not been able to work alone in completing the task given by the teacher, still lack of discipline of children in collecting tasks and not yet motivated children to excel. In learning, Teachers still do not provide character education in learning to children.

The implementation of storytelling methods in improving the character education of children with learning disabilities in SDN 09 Kota Padang is done by using storytelling media because the story has an unquestionable educational value, its broad usage with colored illustrations, a concise storyline with realistic person's characteristic attract all children of different 
ages. The topic of the story in the lesson is "Tuanku Imam Bonjol" for cycle I, "Pangeran Dipenogoro" for cycle II and "Kepahlawanan Jenderal Soedirman" for siklus III" for cycle III.

The use of storytelling methods can improve the character education of children with learning disabilities in SDN 09 Kota Padang. This is due to an increase in the ability of children to do their own schoolwork, the existence of confidence in children to better achievement, a change of attitude (although not significant) to the purpose of learning and the strong desire and seriousness to really follow every learning process.

\section{References}

[1] Goodwin, J. (2015). "Easy Information about Research: Getting the Message Out to People with Learning Disabilities." British Journal of Learning Disabilities. 43(2), pp 93-99 97
[2] Walmsley, J. (2013). "Commentary on Enabling Access to Information by People with Learning Disabilities." Tizard Learning Disability Review. 18(1), pp 16-19 14.

[3] Walmsley, J. (2013). "Commentary on Enabling Access to Information by People with Learning Disabilities." Tizard Learning Disability Review. 18(1), pp 16-19 14.

[4] Walmsley, J. (2013). "Commentary on Enabling Access to Information by People with Learning Disabilities." Tizard Learning Disability Review. 18(1), pp 16-19 14.

[5] Andrews, Dee H \& Hull, Thomas D. (2016). "Storytelling as an Instructional Method: Definitions and Research Questions." The Interdisciplinary Journal of Problem-Based Learning. Volume 3, Number 2, pp 6-23.

[6] Andrews, Dee H \& Hull, Thomas D. (2016). "Storytelling as an Instructional Method: Definitions and Research Questions." The Interdisciplinary Journal of Problem-Based Learning. Volume 3, Number 2, pp 6-23.

[7] Mettetal, Gwyn. (2015). "The What, Why and How of Classroom Action Research", JoSoTL Journal, Volume 2, Number 1,pp 15-24.

[8] Gilles, C., Wilson, J, \& Elias, M. (2016). "Sustaining Teachers' Growth and Renewal Through Action Research, Induction Programs, and Collaboration."Teacher Education Quarterly. 37(1), pp 91-108. 